\title{
Intelligent Fuzzy Logic - Cuckoo Search Algorithm Method for Short-Term Electric Load Forecasting in 150 kV Sulselrabar System
}

\author{
Muhammad Ruswandi Djalal ${ }^{1}$, Faisal ${ }^{2}$ \\ Program Studi Teknik Energi, Jurusan Teknik Mesin, Politeknik Negeri Ujung Pandang \\ Jalan Perintis Kemerdekaan km.10, Makassar \\ 1'wandi@poliupg.ac.id \\ 2faisall@poliupg.ac.id
}

\begin{abstract}
Abstrak
Peramalan beban listrik menjadi hal yang penting, karena dapat memperkirakan konsumsi listrik pada rentang waktu tertentu. Ketelitian dalam peramalan beban listrik dapat meningkatkan keamanan dan kehandalan dalam pengoperasian sistem tenaga listrik seperti pengiriman daya (load flow), pemeliharaan unit pembangkit dan penjadwalan unit pembangkit. Pada penelitian ini digunakan studi kasus sistem Sulselrabar, yang saat ini semakin berkembang, namum masih belum banyak yang membahas tentang kondisi sistem saat ini dan yang akan datang. Beberapa metode untuk memprediksi beban listrik sudah banyak digunakan, mulai dari konvensional sampai berbasis metode cerdas. Pada penelitian ini akan diusulkan metode kecerdasan buatan untuk peramalan beban Jangka Pendek pada sistem Sulselrabar. Metode yang digunakan adalah berbasis Fuzzy Logic dan Cuckoo Search Algorithm. Kombinasi metode Fuzzy logic dan Cuckoo Search dipilih karena kombinasi keduanya menghasilkan optimasi derajat keanggotaan fuzzy logic yang optimal, sehingga hasil peramalan memiliki error yang sangat kecil. Dari hasil penelitian dapat disimpulkan bahwa hasil peramalan beban dengan menggunakan metode Fuzzy Logic yang dioptimasi menggunakan Cuckoo Search Algorithm (FL-CSA) lebih baik dibandingkan dengan Fuzzy Logic yang tidak dioptimasi. Hasil analisa menggunakan data input 3 bulan sebelum hari $\mathrm{H}$, untuk meramal beban selama satu minggu pada tanggal 1 januari sampai 7 januari 2014, dan sebagai pembanding digunakan data hari $H$ yang diramal. Dari hasil simulasi menunjukkan mean absolute percentage error (MAPE) lebih kecil menggunakan FLCSA, untuk MAPE yang paling kecil pada 1 januari 2014 sebesar 0,06785208\%. Sedangkan MAPE tertinggi pada tanggal 4 Januari 2014 sebesar -0,44973\%.
\end{abstract}

Kata kunci : Short-Term Forcasting, Fuzzy Logic, Cuckoo Search Algorithm, MAPE (Mean Absolute Percentage Error (MAPE).

\begin{abstract}
Forecasting the electrical load becomes important, because it can estimate electricity consumption over a certain time range. Accuracy in electric load forecasting can improve safety and reliability in the operation of power systems such as load flow, maintenance of generating units and scheduling of generating units. In this study used case study system Sulselrabar, which is currently growing, but still not much to discuss about the condition of the current system and which will come. Several methods for predicting electrical loads have been widely used, ranging from conventional to smartbased methods. In this research will be proposed method of artificial intelligence for forecasting Short Term load on Sulselrabar system. The method used is based Fuzzy Logic and Cuckoo Search Algorithm. The combination of Fuzzy logic and Cuckoo Search methods is chosen because the combination of both optimizes optimum fuzzy logic membership, so the forecasting results have a very small error. From the results of the research can be concluded that the result of load forecasting using Fuzzy Logic method optimized using Cuckoo Search Algorithm (FL-CSA) is better than Fuzzy
\end{abstract}


Logic that is not optimized. The analysis results using input data 3 months before day $H$, to predict the load for one week on January 1 to 7 january 2014, and as a comparison used the predicted day $H$ data. From the simulation results, the mean absolute percentage error (MAPE) is smaller using FLCSA, for the smallest MAPE on 1 January 2014 of $0.06785208 \%$. While the highest MAPE on January 4, 2014 amounted to $-0.44973 \%$.

Keywords : Short-Term Forcasting, Fuzzy Logic, Cuckoo Search Algorithm, MAPE (Mean Absolute Percentage Error (MAPE.)

\section{Pendahuluan}

Pemanfaatan energi listrik memiliki peranan penting dalam kehidupan manusia. Energi listrik tersebut banyak digunakan pada beberapa sektor seperti pelayanan publik, perhotelan, industri dan masih banyak lagi. Peramalan beban listrik menjadi hal yang penting, karena dapat memperkirakan konsumsi listrik pada rentang waktu tertentu. Ketelitian dalam peramalan beban listrik dapat meningkatkan keamanan dan keandalan dalam pengoperasian sistem tenaga listrik seperti pengiriman daya (load flow), pemeliharaan unit pembangkit dan penjadwalan unit pembangkit.

Pada penelitian ini digunakan studi kasus sistem Sulselrabar, yang saat ini semakin berkembang, namum masih belum banyak yang membahas tentang kondisi sistem saat ini dan yang akan datang. Beberapa metode untuk memprediksi beban listrik sudah banyak digunakan, mulai dari konvensional sampai berbasis metode cerdas. Pada penelitian ini akan diusulkan metode kecerdasan buatan untuk peramalan beban Jangka Pendek pada sistem Sulselrabar. Metode yang digunakan adalah berbasis Fuzzy Logic dan Cuckoo Search Algorithm. Kombinasi metode Fuzzy logic dan Cuckoo Search dipilih karena kombinasi keduanya menghasilkan optimasi derajat keanggotaan Fuzzy Logic yang optimal, sehingga hasil peramalan memiliki error yang sangat kecil.

Penelitian mengenai peramalan beban jangka pendek sebelumnya sudah banyak dilakukan, terutama teknik peramalan beban menggunakan metode cerdas. Penggunaan metode cerdas berbasis Fuzzy Logic sudah banyak dilakukan pada bidang peramalan beban listrik, diantaranya pada penelitian [1-6], telah menggunakan metode ini untuk optimasi peramalan beban, namun pada penelitian ini Fuzzy Logic masih belum sepenuhnya dioptimalkan untuk peramalan beban, hal tersebut dikarenakan membership function (derajat keanggotaan fuzzy) masih menggunakan trialerror atau belum dioptimasi. Pada penelitian [7, 8], adalah beberapa penelitian peramalan beban listrik yang telah dilakukan di sistem kelistrikan $150 \mathrm{kV}$ Suawesi Selatan, Tenggara dan Barat (Sulselrabar). Peramalan beban hari libur nasional menggunakan Radial Basis Function (RBF) Neural Network [7], telah membahas peramalan beban listrik jangka pendek sistem sulselrabar untuk hari libur nasional dari tahun 2003-2011. Estimasi kebutuhan daya listrik Sulawesi Selatan sampai tahun 2017 menggunakan metode konvensional regresi linier[8]. Metode peramalan beban menggunakan metode Cuckoo Search Algorithm telah ada dilakukan sebelumnya $[9,10]$. Penelitian ini akan diusulkan metode algoritma cuckoo search sebagai optimasi untuk membership function fuzzy logic, sehingga hasil yang diharapkan akan semakin optimal. Penggunaan metode cuckoo search juga semakin banyak digunakan dalam bidang ketenagalistrikan, diantaranya [11, 12], dimana metode cuckoo search digunakan untuk mengoptimasi controller PID pada Motor DC, Load Frequency Control (LFC) dan optimasi penempatan Power System Stabilizer (PSS) pada sistem Sulselrabar.

\section{Fuzzy Logic-Cuckoo Search Algorithm 2.1. Fuzzy Logic \\ 2.1.1. Representasi Fungsi Segitiga}

Fungsi keanggotaan kurva segitiga didefinisikan dengan Persamaan berikut dan Parameter a dan c menyatakan "kaki" dari segitiga, sedang b menyatakan "puncak" dari segitiga dapat dilihat pada Gambar berikut [2]. 


$$
\begin{aligned}
& f(x, a, b, c)=\left\{\begin{array}{cc}
0, & x \leq a \\
\frac{x-a}{b-a}, & a \leq x \leq b \\
\frac{c-x}{c-b}, & b \leq x \leq c \\
0, & c \leq x
\end{array}\right\} \\
& f(x, a, b, c)=\max \left(\min \left(\frac{x-a}{b-a}, \frac{c-x}{c-b}\right), 0\right)
\end{aligned}
$$

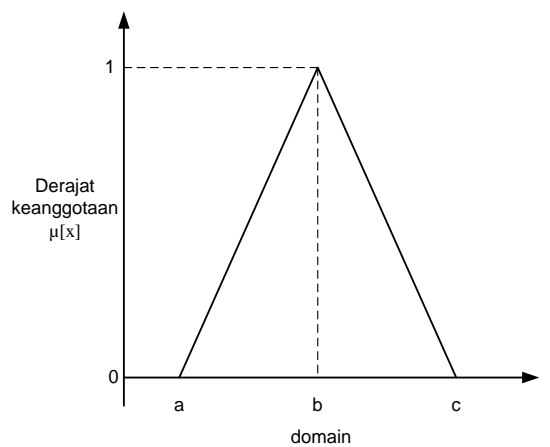

Gambar 1. Persamaan dan Kurva Segitiga

\subsubsection{Representasi Fungsi Trapesium}

Fungsi keanggotaan trapesium didefinisikan dengan Persamaan di bawah ini dan Parameter a dan d menyatakan "kaki" dari trapesium, sedang b dan c menyatakan "bahu" dari trapezium [2].

$$
\begin{aligned}
f(x, a, b, c, d) & =\left\{\begin{array}{cc}
0, & x \leq a \\
\frac{x-a}{b-a}, & a \leq x \leq b \\
1, & b \leq x \leq c \\
\frac{d-x}{d-c}, & c \leq x \leq d \\
0, & d \leq x
\end{array}\right\} \\
f(x, a, b, c, d) & =\max \left(\min \left(\frac{x-a}{b-a}, 1, \frac{d-x}{d-c}\right), 0\right)
\end{aligned}
$$

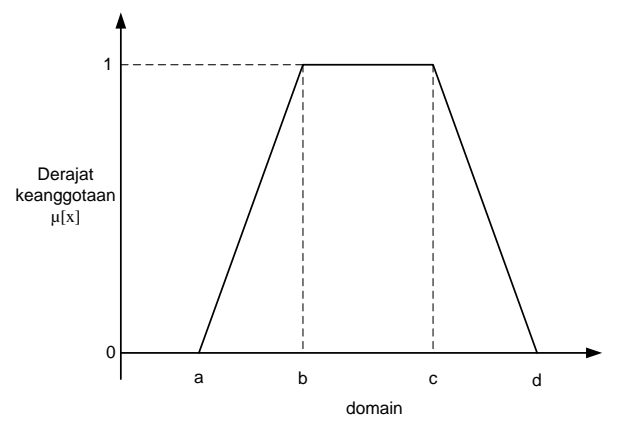

Gambar 2. Persamaan dan Kurva Trapesium

\subsubsection{Fungsi keanggotaan dan Aturan Fuzzy}

Aturan Fuzzy IF-THEN digunakan untuk peramalan beban maksimum. Pada paper ini input dari membership function (antecendent) yaitu $\mathrm{X}, \mathrm{Y}$ dan output membership function (concequent) adalah $Z$ untuk peramalan beban jangka pendek mengikuti persamaan 5 dibawah ini

IF $X$ is $A_{i} A N D Y$ is $B_{i}$ THEN $Z$ is $C_{i}$

Fuzzy set $A_{i}, B_{i}$, dan $C_{i}$ memiliki sebelas fungsi keanggotaan yaitu : Negative Very Big (UNVB and LNVB), Negative Big (UNB and LNB), Negative Medium (UNM and LNM), Negative Small (UNS and LNS), Negative Very Small (UNVS and LNVS), Zero (UZE and LZE), Positive Very Small (UPVS and LPVS), Positive Small (UPS and LPS), Positive Medium (UPM and LPM), Positive Big (UPB and $L P B)$, Positive Very Big (UPVB and LPVB).

\subsection{Cuckoo Search Algorithm}

Algoritma Burung Cuckoo (Cuckoo Search) adalah sebuah metode metaheuristik yang diinspirasi dari perilaku/kebiasaan hidup sehari-hari burung cuckoo dalam berkembang biak. Metode ini dikembangkan oleh Xin-She Yang dan Deb tahun 2009 dan dapat digunakan sebagai optimisasi suatu permasalahan untuk menentukan nilai optimum global baik minimum maupun maksimum. Terinspirasi dari perilaku burung cuckoo ini, sehingga menjadi inspirasi bagi Xin-She Yang dan Deb 
dalam menemukan metode baru dalam dunia optimisasi. Selain itu, karena burung tersebut memiliki keunikan yang tidak dimiliki oleh burung lain. Levy flight adalah random walk yang panjang langkahnya memenuhi distribusi Levy. Distribusi Levy sendiri memiliki fungsi densitas sebagai berikut, $\mu>0$ langkah minimum dan $\gamma$ adalah parameter skala [13].

$$
L(s, \gamma, \mu)=\left\{\begin{array}{c}
\sqrt{\frac{\gamma}{2 \pi}} \exp \left[-\frac{\gamma}{2(s-\mu)^{3 / 2}}\right] \frac{1}{(s-\mu)^{3 / 2}}, 0<\mu<s<\infty \\
0
\end{array}\right.
$$

\subsubsection{Random Walks}

Random walks adalah suatu proses yang terdiri dari serangkaian langkah acak yang berurutan.

$$
Y_{N}=\sum_{i=1}^{N} K_{i}=K_{1}+\ldots+K_{N}=\sum_{i=1}^{N-1} K_{i}+K_{N}=Y_{N-1}+K_{N}
$$

\section{Peramalan Beban Jangka Pendek Menggunakan Fuzzy Logic-Cuckoo Search Algorithm}

\subsection{Pre-processing Data Beban Sistem Kelistrikan Sulselrabar}

Pre-processing data pertama yaitu menghitung MaxWD (i) yaitu beban maksimum rata-rata dari empat hari sebelum hari libur didapatkan dari persamaan sebagai berikut [2] :

$$
\operatorname{MaxWD}(i)=\frac{W D_{(i) h-4}+W D_{(i) h-3}+W D_{(i) h-2}+W D_{(i) h-1}}{4}
$$

Load Differences ( $L D S$ ) untuk beban maksimum pada beban hari libur didapatkan dari perbedaan antara (MaxSD) and MaxWD.

$$
L D_{M A X}(i)=\frac{\operatorname{MaxSD}(i)-\operatorname{Max} W D(i)}{\operatorname{Max} W D(i)} \times 100
$$

Typical Load Differences (TLDs) didapatkan dari merata-rata beban khas pada tipe hari libur yang sama dari historical data beban. TLDs digunakan sebagai dasar untuk peramalan beban maksimum. The Variation of Load Differences (VLDs) didefinisikan sebagai perbedaan antara prilaku beban hari libur dengan tipe prilaku beban hari libur pada tipe hari libur yang sama VLDs dihitung menggunakan persamaan sebagai berikut :

$$
V L D_{\max }(i)=L D_{\max }(i)-T L D_{\max }(i)
$$

\subsection{Optimasi Membership Function Fuzzy Logic Menggunakan Cuckoo Search Algorithm}

Desain dari fuzzifikasi dari input $X$ dan $Y$ menggunakan IT1MF Editor, dimana terdapat 2 trapezoidal membership function dan 9 triangular membership functions dengan range antara -48 sampai 48 untuk proses input dan output, kemudian ada 11 model triangular membership functions digunakan untuk output $Z$. Semua nilai input $X, Y$ and output $Z$ merupkan nilai dari $V L D_{M A X}(I)$ dimana nilai $X$ adalah hari libur yang sama pada tahun sebelum tahun peramalan, $Y$ adalah hari libur sebelumnya (berdekatan) dalam jenis hari libur yang sama pada tahun peramalan dan $Z$ adalah hari libur yang diramal [2]. 


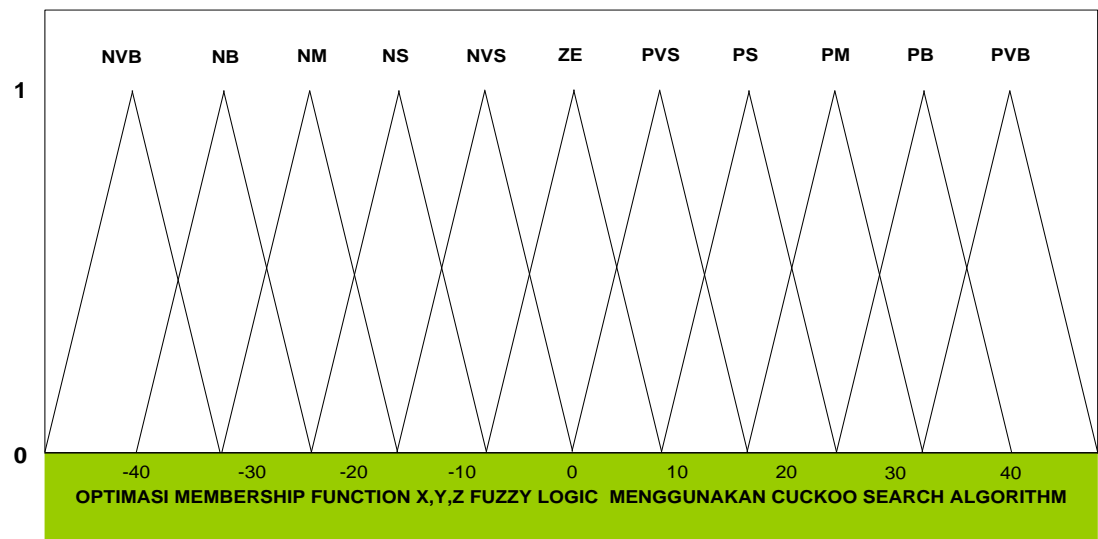

Gambar 3. Desain Membership Function untuk Input X,Y,Z yang dioptimasi dengan CSA

\subsection{Post-processing}

Setelah mendapatkan Forecast VLD MAX maka selanjutnya mencari Forecast Load Difference sebagai berikut :

$$
\text { Forecast } L D_{M A X}(i)=\text { Forecast } V L D_{M A X}(i)+T L D_{M A X}(i)
$$

Beban Puncak Peramalan (MW) dapat dihitung menggunakan persamaan sebagai berikut :

$$
P^{\prime}{ }_{M A X}=\operatorname{MaxWD}(i)+\frac{\left(\text { Forecast } L D_{M A X}(i) x \operatorname{Max} W D(i)\right)}{100}
$$

Persentase error antara nilai peramalan dengan nilai aktual dapat hitung dengan persamaan berikut:

$$
\text { Error } \%=\left|\frac{P_{M A X}^{\prime}(i)-\operatorname{MaxSD}(i)}{\operatorname{MaxSD}(i)}\right| x 100
$$

\section{Hasil dan Pembahasan}

Optimasi peramalan beban menggunakan FL-CSA menggunakan input data tiga bulan sebelum hari $\mathrm{H}$. Dari hasil simulasi menunjukkan Mean Absolute Percentage Error (MAPE) lebih kecil menggunakan FL-CSA, untuk MAPE yang paling kecil pada 1 januari 2014 sebesar $0,06785208 \%$. Sedangkan MAPE tertinggi pada tanggal 4 Januari 2014 sebesar $-0,44973 \%$. Berikut disajikan untuk hasil MAPE terbesar dan terkecil, untuk hasil keseluruhan peramalan dapat dilihat pada Tabel 2 dan 3. Tabel 1 menunjukkan parameter algoritma cuckoo yang digunakan.

Tabel 1. Cuckoo Search Algorithm Parameter

\begin{tabular}{lc}
\hline \multicolumn{1}{c}{ Parameter } & Jumlah \\
\hline Jumlah Sarang & 25 \\
Rasio Pencarian Sarang & 0.25 \\
Toleransi & $1.0^{-5}$ \\
Jumlah Parameter & 30 \\
Beta & $3 / 2$ \\
Iterasi & 15 \\
\hline
\end{tabular}



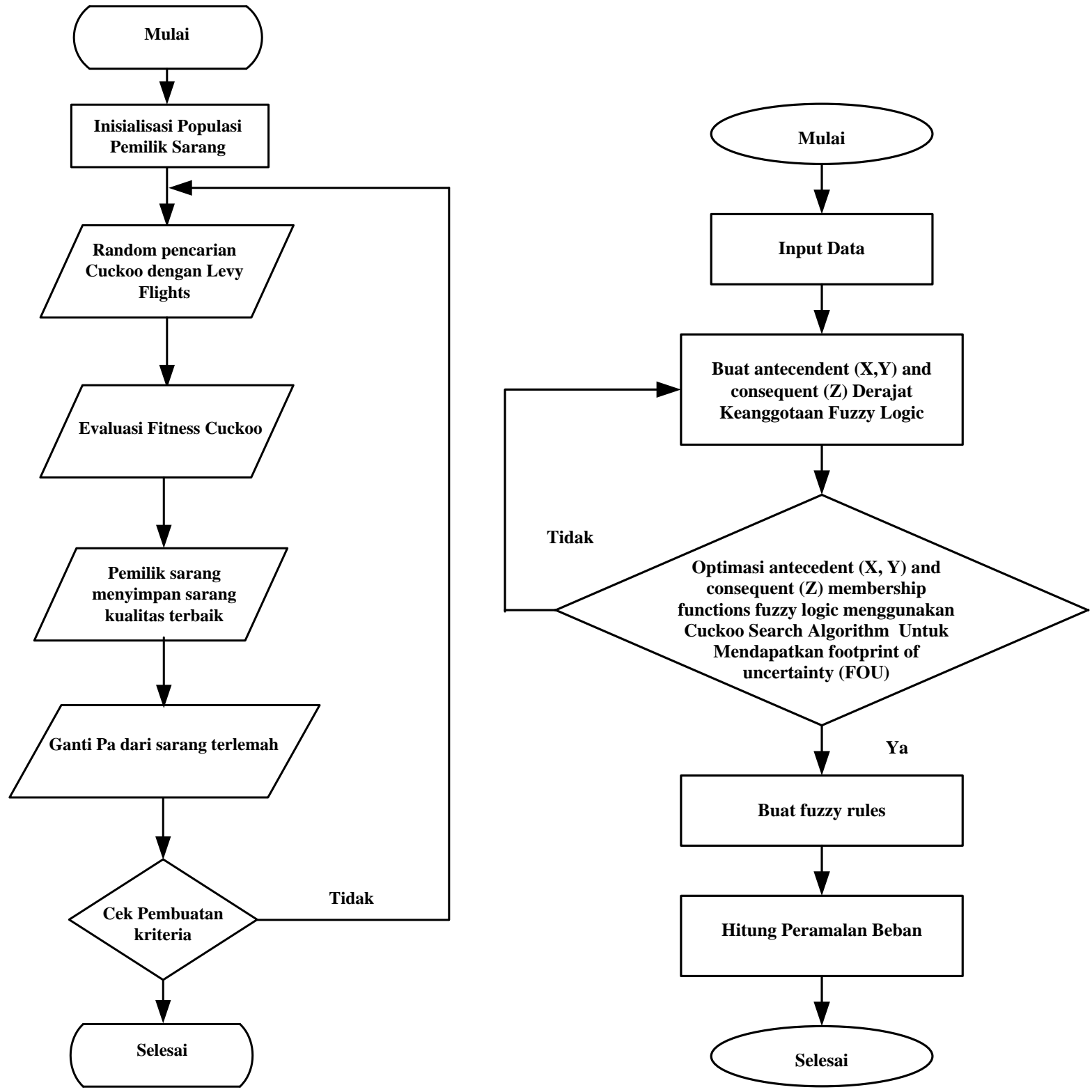

Gambar 4. Diagram Alir Cuckoo Search dan Penelitian

Gambar 4 menunjukkan flowchart algoritma cuckoo dalam mengoptimasi membership function X,Y,Z fuzzy logic type-1. Algoritma cuckoo disini digunakan sebagai algoritma optimasi membership function fuzzy logic. Algoritma cuckoo dibuat di $m$-file matlab dan memerlukan beberapa parameter. Berikut parameter Cuckoo yang digunakan dapat di lihat pada Tabel 1, seperti : Discovery rate of alien eggs / solutions = 0,25; Number of nests (or different solutions) $=25$; Beta = 1,5.

\section{MAPE Terbesar}

Dari hasil simulasi didapatkan MAPE terbesar pada tanggal 4 January 2014, yaitu sebesar -0.62916 dengan menggunakan FL-CSA. Berikut gambar 5-8 hasil untuk peramalan beban pada tanggal 4 
January 2014 untuk masing-masing Forecast VLD Max, Error VLD Max, Load Forecasting \& Error Load Forecasting.

MAPE Terkecil

Dari hasil simulasi didapatkan MAPE terkecil pada tanggal 1 January 2014, yaitu sebesar 0,06785208\%, dengan menggunakan FL-CSA. Berikut gambar 9-12 hasil untuk peramalan beban pada tanggal 1 January 2014 untuk masing-masing Forecast VLD Max, Error VLD Max, Load Forecasting \& Error Load Forecasting.

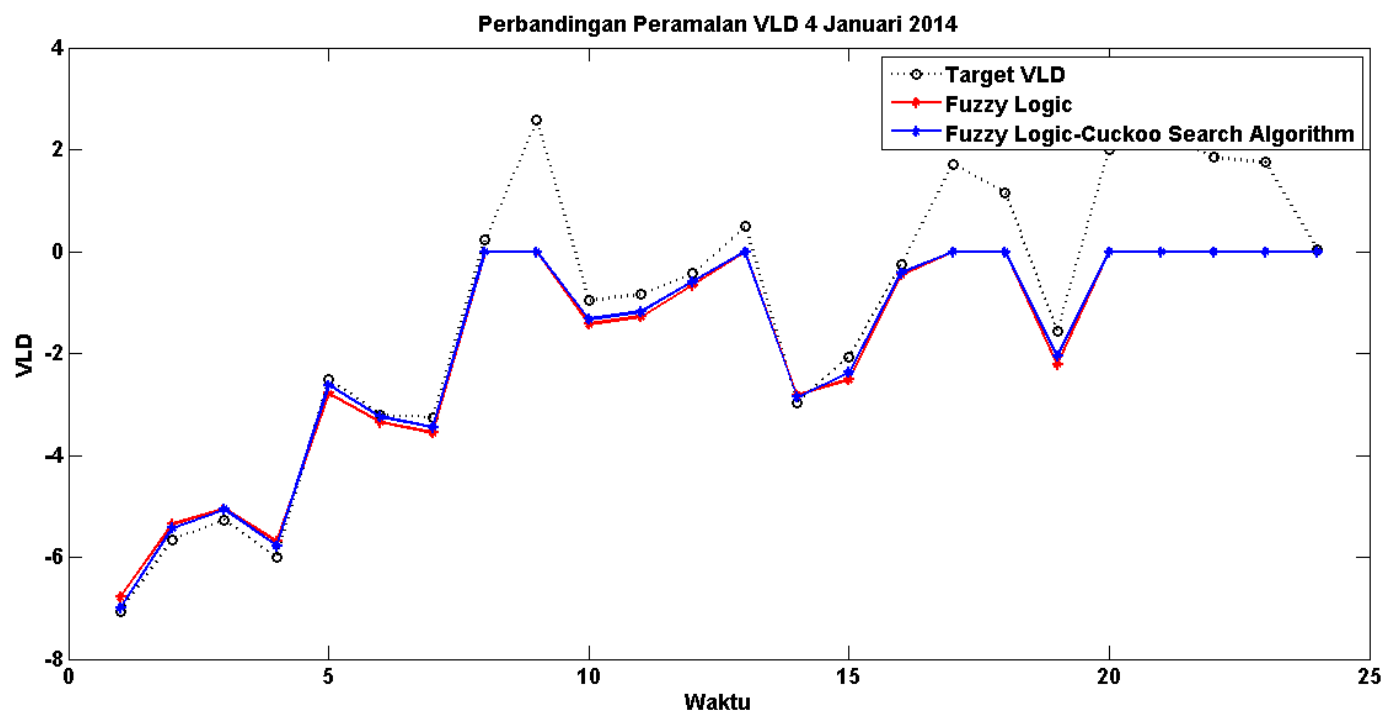

Gambar 5. Perbandingan Hasil Peramalan VLD 4 January 2014

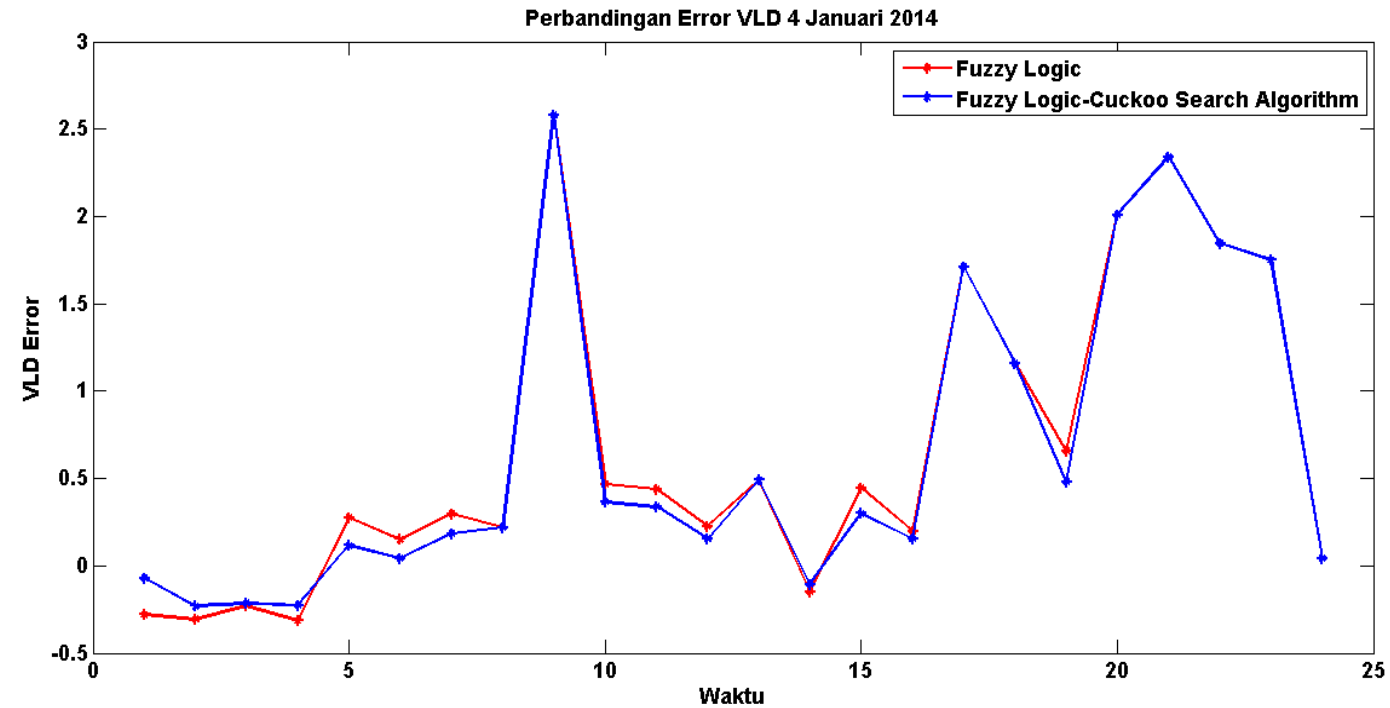

Gambar 6. Perbandingan Error Peramalan VLD 4 January 2014 


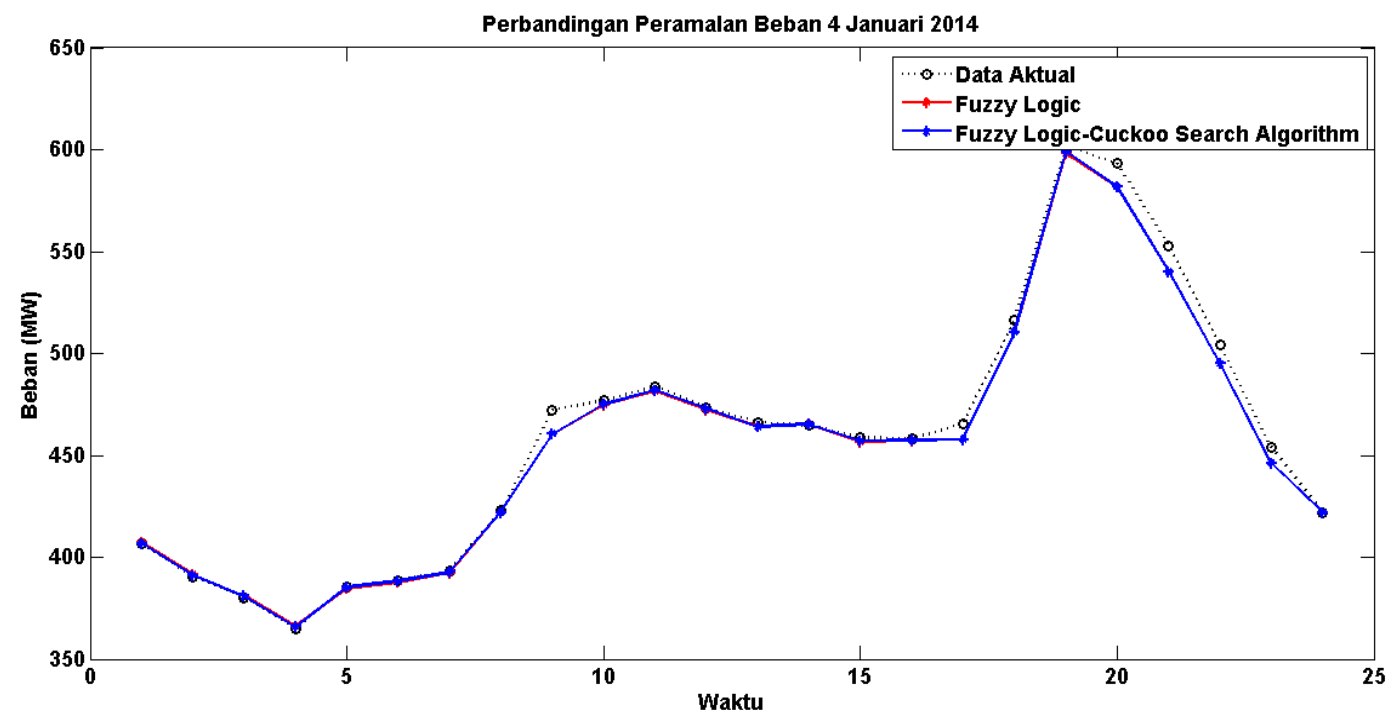

Gambar 7. Perbandingan Hasil Peramalan Beban 4 January 2014

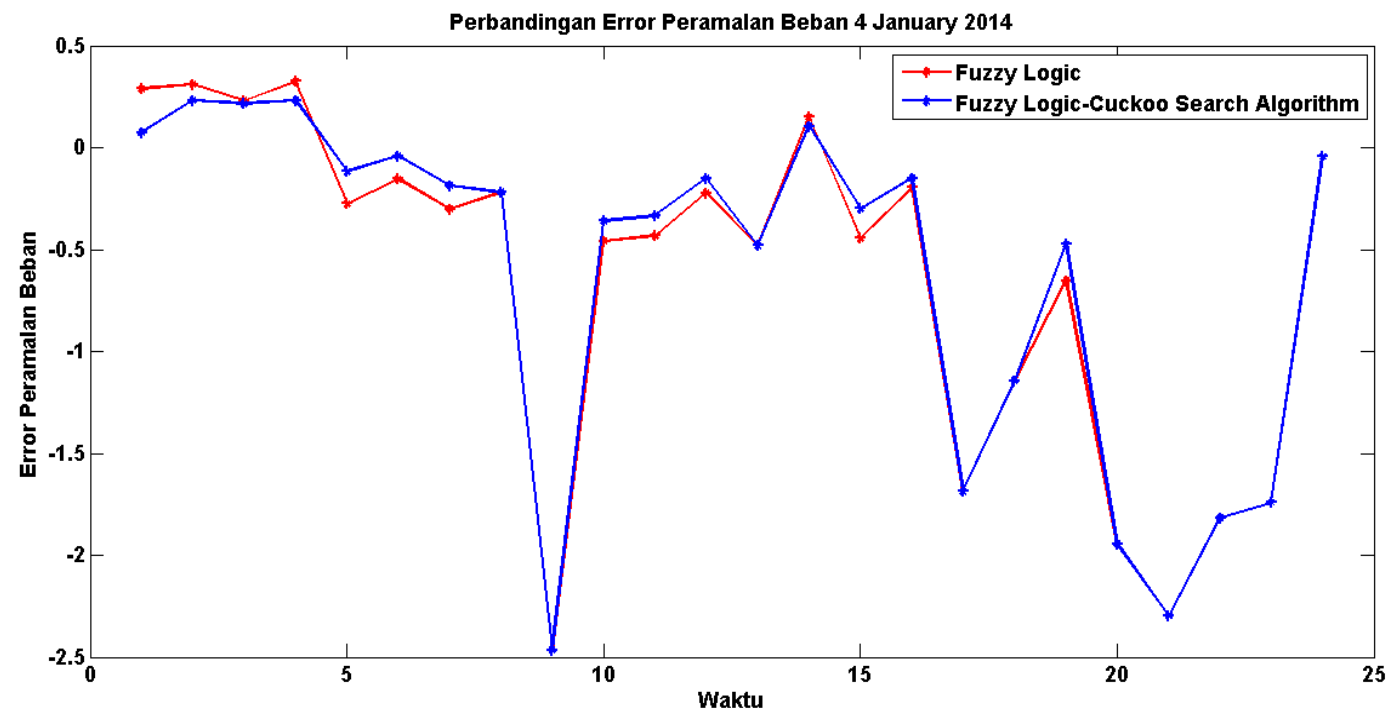

Gambar 8. Perbandingan Error Peramalan Beban 4 Januari 2014 


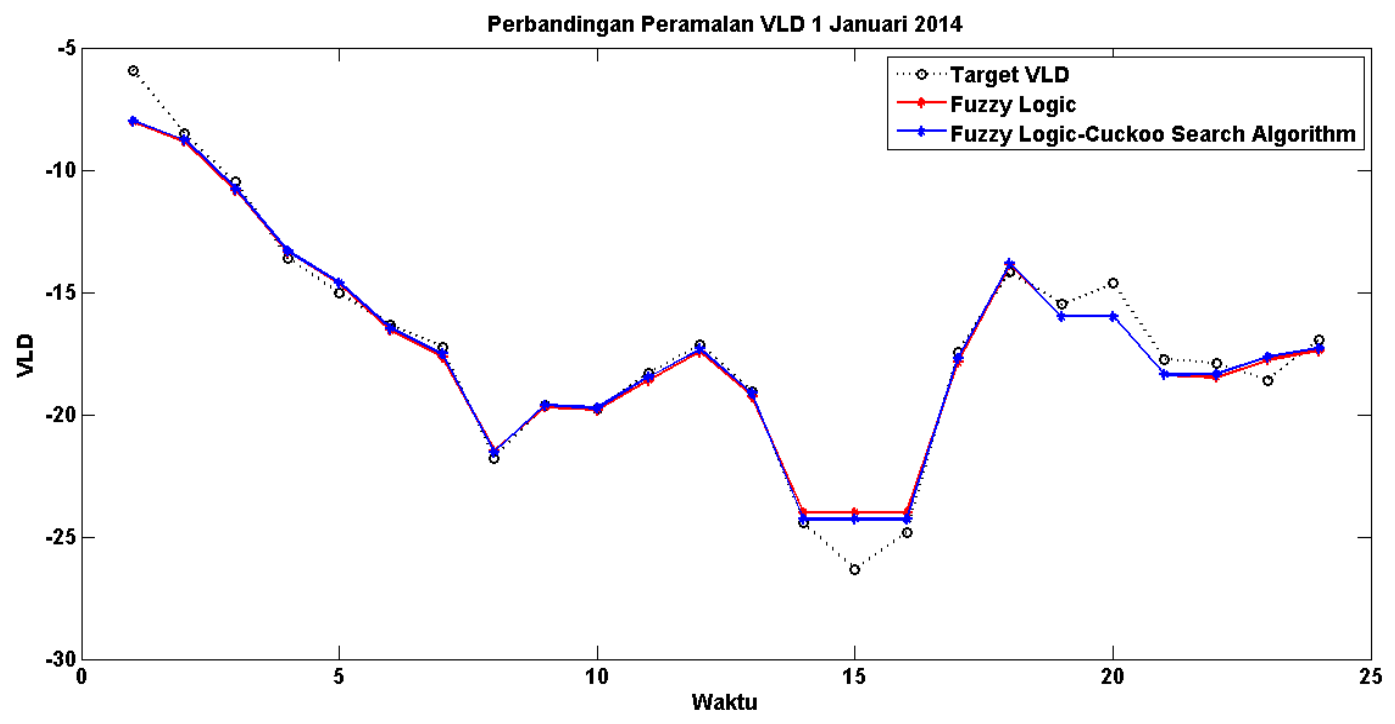

Gambar 9. Perbandingan Hasil Peramalan VLD 1 January 2014

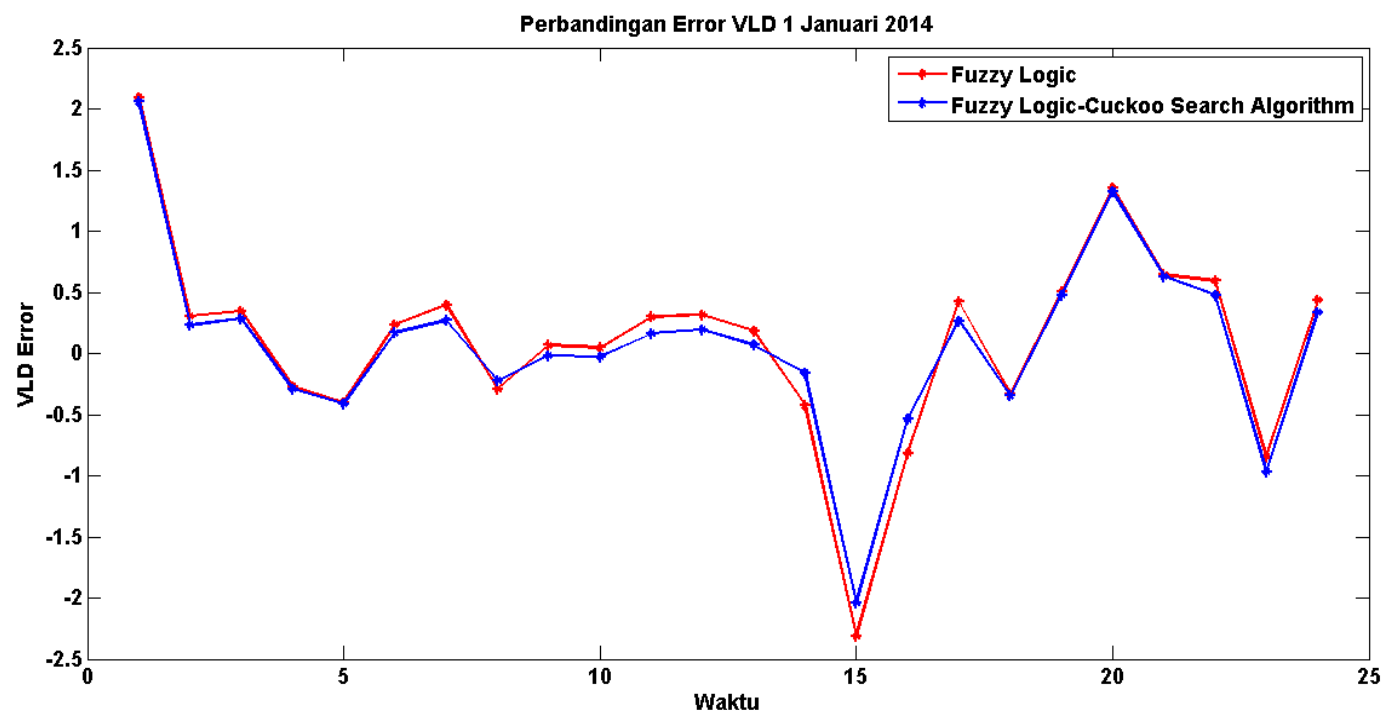

Gambar 10. Perbandingan Error Peramalan VLD 1 Januari 2014 


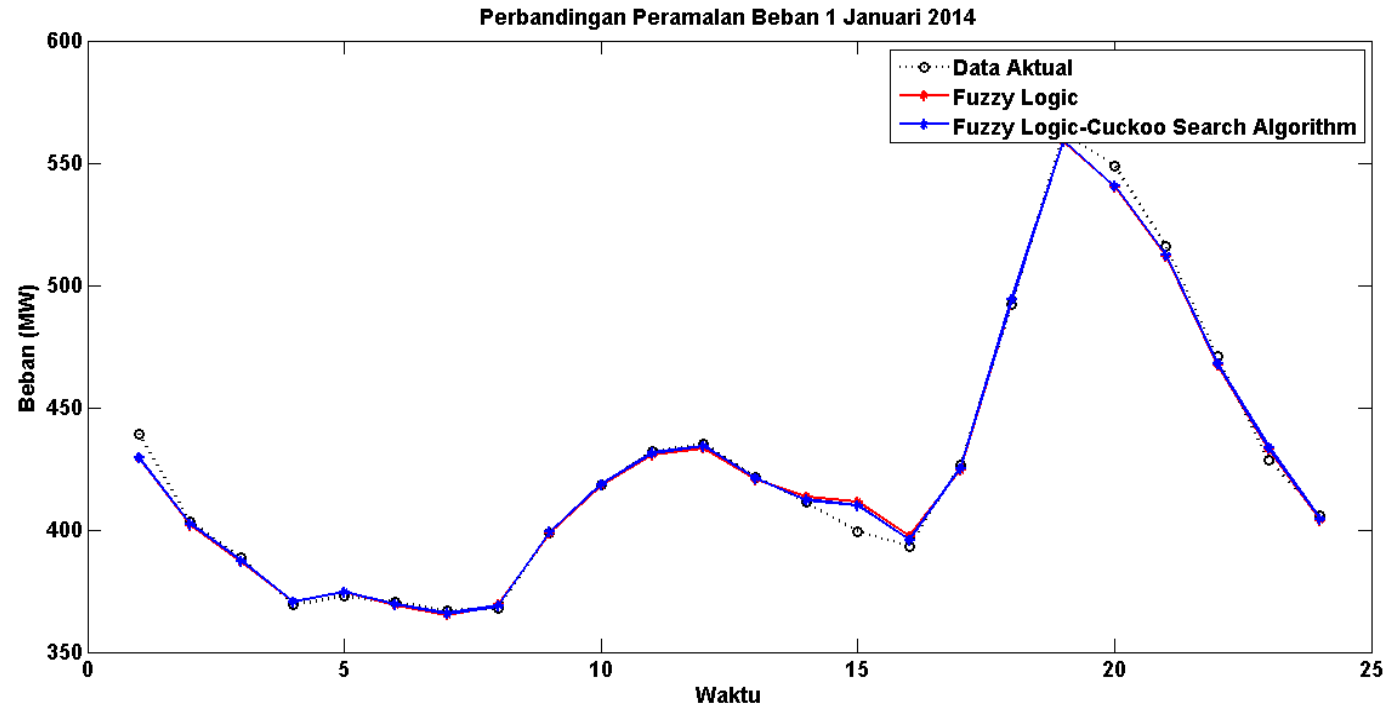

Gambar 11. Perbandingan Hasil Peramalan Beban 1 January 2014

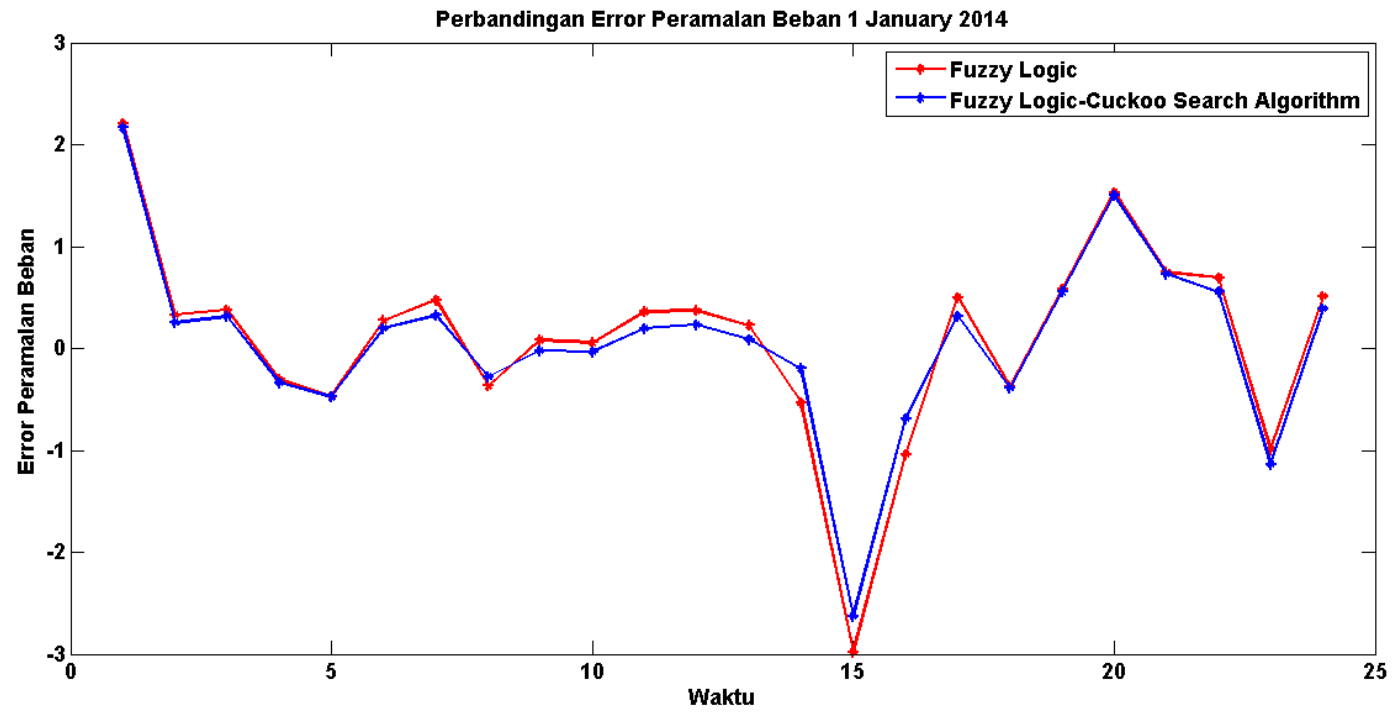

Gambar 12. Perbandingan Error Peramalan Beban 1 Januari 2014

Tabel 2 dan 3 menunjukkan hasil peramalan beban selama 24 Jam pada tanggal 1 dan 4 januari 2014, data input yang digunakan bulan Oktober, November dan Desember 2013, masing-masing 4 hari sebelum hari- $\mathrm{H}$ disetiap tanggal yang sama disetiap bulannya. Nilai error VLD forecast menggunakan Fuzzy Logic sebesar 0.105673 dan dengan menggunakan FL-CSA sebesar 0.080138, sedangkan MAPE peramalan beban menggunakan Fuzzy Logic sebesar 0.09440529 dan dengan menggunakan FL-CSA sebesar 0.06785208.

\section{Kesimpulan}

Optimisasi footprint of uncertainty (FOU) dari Fuzzy Logic (FL) menggunakan Cuckoo Search Algorithm (CSA) untuk peramalan beban jangka pendek selama 24 jam pada tanggal 1 dan 4 Januari 2014 studi kasus sistem kelistrikan 150kV Sulselrabar Sistem menunjukan nilai Main Absolute 
Percentage Error (MAPE) untuk metode FL-CSA lebih kecil dibandingkan dengan metode sebelumnya menggunakan Fuzzy Logic tanpa dioptimasi. Nilai MAPE terkecil menggunakan metode FL-CSA terjadi pada tanggal 1 Januari 2014 yaitu sebesar $0.06785208 \%$. Nilai MAPE terbesar pada tanggal 4 Januari 2014 yaitu sebesar $0.09440529 \%$. Nilai MAPE tersebut masih dibawah batas nilai toleransi yang diijinkan. Dengan demikian dapat disimpulkan bahwa, dengan menggunakan metode yang diusulkan, FL-CSA, dapat mengoptimalkan peramalan beban listrik.

\section{Daftar Pustaka}

[1] A. Dharma, I. Robandi, And M. H. Purnomo, "Application Of Short Term Load Forecasting On Special Days Using Interval Type-2 Fuzzy Inference Systems: Study Case In Bali Indonesia," Journal of Theoretical \& Applied Information Technology, vol. 49, 2013.

[2] A. Ramadhani, Agus Dharma, \& Imam Robandi, "Optimization FOU of Interval Type-2 Fuzzy Inference System Using Big Bang - Big Crunch Algorithm for Short Term Load Forecasting on National Holiday Case Study: South and Central Kalimantan-Indonesia," International Review of Electrical Engineering (IREE), vol. 10, pp. 123-130, 2015.

[3] P. P. Manoj and A. P. Shah, "Fuzzy logic methodology for short term load forecasting."

[4] D. Ali, M. Yohanna, M. Puwu, and B. Garkida, "Long-term load forecast modelling using a fuzzy logic approach," Pacific Science Review A: Natural Science and Engineering, vol. 18, pp. 123-127, 2016.

[5] F. Tuaimah, "Iraqi Short Term Electrical Load Forecasting Based On Interval Type-2 Fuzzy Logic," World Academy of Science, Engineering and Technology, International Science Index 92, International Journal of Electrical, Computer, Energetic, Electronic and Communication Engineering, vol. 8, pp. 1255 - 1261, 2014.

[6] I. C. L. P. C. Taylor, "Memetic Type-2 Fuzzy System Learning for Load Forecasting," 2015.

[7] A. Imran, "Prediksi Beban Puncak Hari Libur Nasional Berbasis Radial Basis Function Neural Network," Tesis Unhas, 2012.

[8] Harifuddin, "Estimasi Kebutuhan Daya Listrik Sulawesi Selatan Sampai Tahun 2017," Media Elektrik, vol. 2, 2007.

[9] E. H. Chang, G. N. Zhu, and J. W. Chen, "A combined model based on cuckoo search algorithm for electrical load forecasting," in Applied Mechanics and Materials, 2015, pp. 278282.

[10] F.-A. P. Pooria Lajevardy, Hassan Rashidi, Hossein Rahimi, "A Hybrid Method for Load Forecasting In Smart Grid Based On Neural Networks and Cuckoo Search Optimization Approach," International Journal of Renewable Energy Resources, vol. 5, 2015.

[11] W. Tan, M. Hassan, M. Majid, and H. A. Rahman, "Allocation and sizing of DG using Cuckoo Search algorithm," in Power and Energy (PECon), 2012 IEEE International Conference on, 2012, pp. 133-138.

[12] W. Buaklee and K. Hongesombut, "Optimal DG allocation in a smart distribution grid using Cuckoo Search algorithm," in Electrical Engineering/Electronics, Computer, Telecommunications and Information Technology (ECTI-CON), 2013 10th International Conference on, 2013, pp. 1-6.

[13] M. R. Djalal, D. Ajiatmo, A. Imran, and I. Robandi, "Desain Optimal Kontroler PID Motor DC Menggunakan Cuckoo Search Algorithm," SENTIA 2015, vol. 7, 2015. 
Tabel 2. Hasil Peramalan VLD 1 Januari 2014

\begin{tabular}{cccccc}
\hline \multirow{2}{*}{ Waktu } & \multirow{2}{*}{ Target (MW) } & \multicolumn{2}{c}{ VLD Fuzzy Logic } & \multicolumn{2}{c}{ VLD Fuzzy Logic - CSA } \\
\cline { 3 - 6 } & & VLD & Error & \multicolumn{1}{c}{ VLD } & Error \\
\hline $01: 00$ & -5.92266 & -8.01831 & 2.095653 & -7.98047 & 2.057814 \\
$02: 00$ & -8.53246 & -8.837 & 0.304539 & -8.76375 & 0.231296 \\
$03: 00$ & -10.4977 & -10.8422 & 0.344545 & -10.7826 & 0.284915 \\
$04: 00$ & -13.6077 & -13.338 & -0.26962 & -13.3153 & -0.2924 \\
$05: 00$ & -15.031 & -14.6277 & -0.40331 & -14.6192 & -0.4118 \\
$06: 00$ & -16.3209 & -16.5533 & 0.2324 & -16.4888 & 0.167856 \\
$07: 00$ & -17.2466 & -17.6438 & 0.397229 & -17.5163 & 0.269662 \\
$08: 00$ & -21.7699 & -21.4758 & -0.29408 & -21.5466 & -0.22325 \\
$09: 00$ & -19.6277 & -19.6956 & 0.067932 & -19.6106 & -0.01708 \\
$10: 00$ & -19.7583 & -19.8042 & 0.045818 & -19.7299 & -0.02847 \\
$11: 00$ & -18.3006 & -18.5997 & 0.299091 & -18.4622 & 0.161615 \\
$12: 00$ & -17.1231 & -17.4379 & 0.314742 & -17.3186 & 0.195498 \\
$13: 00$ & -19.0644 & -19.2492 & 0.184843 & -19.1344 & 0.070019 \\
$14: 00$ & -24.4268 & -24 & -0.42681 & -24.2688 & -0.158 \\
$15: 00$ & -26.3136 & -24 & -2.31358 & -24.2722 & -2.04141 \\
$16: 00$ & -24.8148 & -24 & -0.81481 & -24.2779 & -0.53687 \\
$17: 00$ & -17.4449 & -17.8659 & 0.421061 & -17.7094 & 0.264485 \\
$18: 00$ & -14.1729 & -13.8435 & -0.32933 & -13.8271 & -0.34573 \\
$19: 00$ & -15.4827 & $-1.60 \mathrm{E}+01$ & 0.501501 & $-1.60 \mathrm{E}+01$ & 0.477045 \\
$20: 00$ & -14.6354 & $-1.60 \mathrm{E}+01$ & 1.352276 & $-1.60 \mathrm{E}+01$ & 1.32533 \\
$21: 00$ & -17.7354 & -18.3798 & 0.644372 & -18.3655 & 0.630061 \\
$22: 00$ & -17.8816 & -18.4734 & 0.591829 & -18.3577 & 0.476115 \\
$23: 00$ & -18.6057 & -17.7596 & -0.84615 & -17.6377 & -0.96802 \\
$24: 00$ & -16.9393 & -17.3753 & 0.436024 & -17.2739 & 0.334623 \\
& & $\mathbf{R a t a 2}$ & $\mathbf{0 . 1 0 5 6 7 3}$ & $\mathbf{R a t a 2}$ & $\mathbf{0 . 0 8 0 1 3 8}$ \\
\hline
\end{tabular}

Tabel 3. Hasil Peramalan Beban 1 Januari 2014

\begin{tabular}{|c|c|c|c|c|}
\hline \multirow{2}{*}{ Waktu } & \multicolumn{2}{|c|}{ Pramal Menggunakan Fuzzy Logic } & \multicolumn{2}{|c|}{ Pramal Menggunakan Fuzzy Logic - CSA } \\
\hline & $\mathbf{P}(\mathrm{MW})$ & Error & $\mathbf{P}(\mathrm{MW})$ & Error \\
\hline 01:00 & 429.3410155 & 2.20467963 & 429.5157811 & 2.1648715 \\
\hline 02:00 & 401.9374716 & 0.33290231 & 402.2603531 & 0.25283846 \\
\hline 03:00 & 386.9430028 & 0.38025775 & 387.1986272 & 0.31444641 \\
\hline 04:00 & 370.54757 & -0.30794239 & 370.6436488 & -0.33395111 \\
\hline 05:00 & 374.6158962 & -0.46823187 & 374.6526425 & -0.47808687 \\
\hline 06:00 & 369.2199677 & 0.27550569 & 369.5032593 & 0.19899003 \\
\hline 07:00 & 365.235626 & 0.47804408 & 365.7990312 & 0.3245235 \\
\hline 08:00 & 369.1927477 & -0.36775437 & 368.8669368 & -0.27918028 \\
\hline 09:00 & 398.6086925 & 0.08304694 & 399.0233024 & -0.02088093 \\
\hline $10: 00$ & 418.2660653 & 0.05589838 & 418.6453402 & -0.03472884 \\
\hline $11: 00$ & 430.6789996 & 0.36114204 & 431.3965071 & 0.19514458 \\
\hline $12: 00$ & 433.4783542 & 0.37270645 & 434.0927366 & 0.23150158 \\
\hline $13: 00$ & 420.5846782 & 0.22425968 & 421.1719109 & 0.08494986 \\
\hline $14: 00$ & 413.519127 & -0.53465111 & 412.1340902 & -0.19792138 \\
\hline $15: 00$ & 411.3842449 & -2.97735736 & 409.9850124 & -2.62710265 \\
\hline $16: 00$ & 397.2732815 & -1.04107063 & 395.8770406 & -0.68595569 \\
\hline $17: 00$ & 424.3065494 & 0.49795994 & 425.0961758 & 0.31278856 \\
\hline $18: 00$ & 493.9456266 & -0.37097184 & 494.0365818 & -0.38945416 \\
\hline $19: 00$ & 558.7156299 & 0.58086944 & 558.8748188 & 0.55254301 \\
\hline $20: 00$ & 540.3383406 & 1.53108201 & 540.5057578 & 1.50057263 \\
\hline $21: 00$ & 512.0896695 & 0.74627487 & 512.1751801 & 0.72970111 \\
\hline $22: 00$ & 467.5172044 & 0.69095218 & 468.1531865 & 0.55585816 \\
\hline $23: 00$ & 432.9889454 & -0.99103079 & 433.6009045 & -1.13376511 \\
\hline $24: 00$ & 403.972623 & 0.509156 & 404.4534084 & 0.39074762 \\
\hline & MAPE & 0.09440529 & MAPE & 0.06785208 \\
\hline
\end{tabular}

